\title{
The Analysis of Students' Mathematical Reasoning Ability in Completing Mathematicalproblems on Geometry
}

\author{
Widya Rizkha Sandy, Siti Inganah, Anis Farida Jamil \\ Study Program of Mathematics Education \\ Faculty of Teacher Training and Education, \\ University of Muhammadiyah Malang \\ riska.s199@gmail.com
}

\begin{abstract}
This study aimed to describe the level of students' reasoning ability to solve the problems on flat sides of Geometry with the level of mathematical reasoning ability of high, moderate and low. The types and the research approaches used were descriptive qualitative and quantitative research design. The research subjectswere 6 students from class VIIIF. The form of data collection included 4 items ofwritten questions test and interview on the subject selected. Based on the analysis, the average value of the entire instrument about the mathematical reasoning abilities gained $71.5 \%$ for the indicators that carried out the calculations based on mathematical formulas or rules applicable. While $73.33 \%$ and $71.5 \%$ for the indicator of conclusions and $66.67 \%$ for the indicator ofestimation, that ifsummedup and averaged the percentage was $69 \%$. The ability of class VIIIF students' mathematical reasoning was fair.
\end{abstract}

Keywords: Mathematical Reasoning, Problem solving, Geometry.

\section{INTRODUCTION}

Education is a major pioneer in improving the quality of human resources. Education is the way to form of people ability to use rational response in dealing with the problems that arise in the quest for a better future. Mathematics as a subject in school is considered very important role since it can enhance students' knowledge of mathematics in logical thinking, rational, critical, accurate, effective, and efficient. Mathematical knowledge must be mastered by the students as early as possible. Mathematics is used as the basic of all lesson studies. Hence, it needs to be given to all students at every level of education (Depdiknas,2006). Therefore, learn mathematicsappropriately is the first step in the control of development concept. In mastering the concepts, student's reasoning is required to give the understandingabout the learning process independently. According to Ruseffendi (2006) and Soedjadi (2000) Mathematical reasoning needs the variation of cognitive abilities and thorough cognitive activities in the solution of problems process. According Wahyudin (2008) Reasoning is part of the process of mathematical problem solving.

Depdiknas (Sadiq,2004) states Mathematics and its reasoning cannot be separated from one to each other.Both complementary reasoningsare understood and practiced by studying mathematics, while mathematics problems are understood through reasoning. Mathematical reasoning is part of the problem-solving process that involves thinking and reasoning skills of students in seeking alternative solutions to problems. (Singapore Ministry of Education, 2009). In real life - the reason and think analytically always focused on the pattern, structure or form of symbolic rules. (NCTM 2000). The patterns used are observation, conjecture and evidence. With the mastery of mathematical reasoning abilities, the students can solve mathematical problems in the learning process. 
Achievement of the average Indonesian students' mathematics skill is lower than International standards. TIMSS International Benchmark, (2011) that written back in Puspendik (2012) in which Indonesia is ranking 38th with a score of 386 from 42 countries. In 2015 Indonesia was ranked 45 th out of 50 countries received a score of 397. Although there was an increase from the previous year, it obviously need repairing that Indonesian Students need to strengthen the ability on integrating information, drawing conclusions, and generalizing knowledge to the other things (Puspendik 2016). These three things are not separated from aspects of students' mathematical reasoning that need to be improved. Results of preliminary observations also showed that the average of mathematics achievement for students of VIIIFgrade inState of Islamic Junior High School 1 Trenggalek only reaches $71.56 \%$. The percentage of final daily test values ranged between $60-75 \%$ of the total number of students. Therefore, this research wasmore focused on the "Analysis of students' Mathematical Reasoning Ability in completing the Mathematics Problem solving on Geometry".

\section{RESEARCH METHOD}

The subjects in this study were 6 students of class VIII F in State of Islamic Junior High School 1 Trenggalek. The scope of the materials used were flat geometry that taught in class VIII. This study used mathematical reasoning ability test instrument.This type of research was descriptive. In this study the researcher revealedthe students' reasoning abilities of State of Islamic Junior High School 1 Trenggalek in solving problems related to the understanding of the concepts and procedures on the subject materials of Flat sides on Geometry that learnt by class VIII. This research used qualitative and quantitative approaches. Qualitative data in the form of descriptions on how the students completedthe mathematics problems of flat sides on geometry material from mathematical reasoning aspects. Quantitative data was derived from scoring of each mathematical indicators.

In this study, the indicators used mathematical reasoning and examined the following aspects: 1) the presentation of mathematical statements orally,writing or in the pictures or diagrams,2) Conclusion, the preparation of evidence, reasoning or evidence of some solutions, 3)draw conclusions from a statement,and 4)Determination of a pattern or make the symptoms of a problem to manufacture the generalizations(Iqbal, 2015).

\section{RESULT AND DISCUSSION}

The result of written tests was gained from the observation of 6 students by using mathematical reasoning skills test instruments. The assessment of instruments in the form of mathematical reasoning ability tests obtained from 4 descriptive questions. The result of this study were the data from the analysis of student answers based on scoring guidelines mathematical reasoning ability (Table 2). The scoring resultof mathematical reasoning ability on the material of flat sides geometry were presented in Tables 1 and 2 below.

\begin{tabular}{lllllll}
\multicolumn{5}{c}{ table 1 The Scoring Result of Students' Reasoning Ability from Each of Indicator Problem } \\
\hline NO & $\begin{array}{l}\text { The number } \\
\text { students }\end{array}$ & $\begin{array}{l}\text { The } \\
\text { maximum } \\
\text { score }\end{array}$ & $\begin{array}{l}\text { The } \\
\text { minimum } \\
\text { score }\end{array}$ & Average & $\begin{array}{l}\text { Percentage } \\
(\%)\end{array}$ \\
\hline 1 & 6 & 4 & 1 & 2,66 & 71.50 \\
2 & 6 & 4 & 1 & 3 & 73.33 \\
3 & 6 & 4 & 1 & 2,66 & 71.50 \\
4 & 6 & 4 & 0 & 1.67 & 66.67 \\
& & & & & \\
\hline
\end{tabular}


table 2 The Overall Scoring Results ofStudents' Reasoning Ability from Each of Indicator Problem

\begin{tabular}{llllll}
\hline Subject & Question 1 & Question2 & Question3 & Question 4 & $\begin{array}{l}\text { Percentage } \\
(\%)\end{array}$ \\
\hline SA & 4 & 4 & 4 & 4 & 100 \\
\hline SB & 4 & 4 & 4 & 0 & 75 \\
\hline SC & 2 & 4 & 2 & 3 & 71.81 \\
\hline SD & 3 & 4 & 1 & 0 & 50 \\
\hline SE & 1 & 1 & 4 & 0 & 37.5 \\
\hline SF & 2 & 1 & 1 & 0 & 25 \\
\hline
\end{tabular}

The average percentage of mathematical reasoning skills on students' ability to carry out the calculations based on the formula / mathematical rules that apply to the questions from number 1 and 3 was $71.5 \%$, it meant that most of the students were able to carry out the calculations based on mathematical formulas orapplicable rules, the students'average percentage mathematical reasoning skills in making an estimation in question 2 was $73.33 \%$, it meant, the studentswere able to make the calculations correctly. While for Question 4 was $66.67 \%$, it showed most of the students were able to make calculations averagely correct. The students' percentage of mathematical reasoning abilities for the whole questions reached $69.59 \%$, it could be concluded that most of the students in State of Islamic Junior High School 1 Trenggalek classified as having the ability of mathematical reasoning well. The following were some sample responses of the students in answering questions that include indicators 1 through 4.

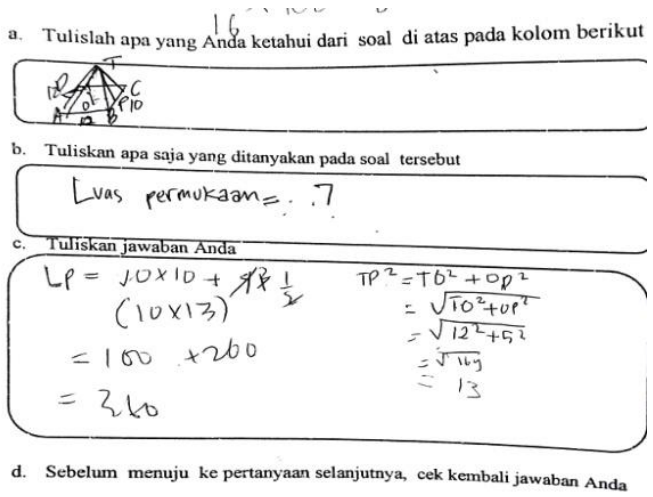

Picture 1. Students' answer in answering the Question of Indicator1

SC answered the firstQuestion on the surface area of the pyramid are not systematically and used some steps: 1) SC no longer write the length of ribs 10, and 2 of height. meanwhile, indicated directly by a small image that was not so clear. 2) SC was asked to write down what was the surface area of the pyramid and the pyramid sketch. 3) SC wrote the correct answer that the rectangular pyramid surface area equal to 360 systematic measures and appropriated with the formula quadrilateral pyramid surface area. Step (1) and (2) were an understanding of the stages and the early stages ofplanning Polya. While the step (3) was the final stage of planning that was characterized by writing Polya formula pyramid surface area and stage of final solving problems that signed by the views of the surface area of the pyramid 360 and rechecking that could be seen at the interview stage that students could conclude that the area of the surface of the pyramid 360 was correct. So SC received a total score of 2 since SC did not present a mathematical statement in writing, but did the calculations correctly. This showed that the first indicator of mathematical reasoning ability was achieved with rudimentary. Based on the interview the student could not answer thefirst indicator correctly because the calculation 
was based on the formula of mathematical rules andthe result was wrong then the score was 2 point.

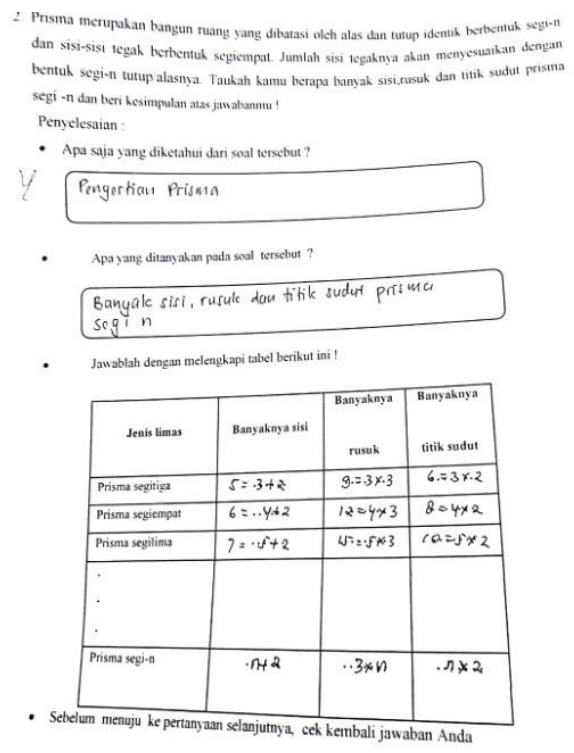

Figure 2.Students' answer in answering the Question of Indicator 2

SB answered the questions number 2 on many sides, ribs and the vertexes on the prism based on the type of prism. The steps that taken by SB to answer the questions were: 1) wrote down what was known about the exact form of the prism, it showed that SB understoodthe questionscorrectly.2) Described what was being asked about the sides, ribs and vertexes prism, it meanthe / she did the initial planning steps correctly too. 3) Answered correctly according to what was asked about, for example: triangular prism had 9 ribs, 5 sides and 6 of vertexes.

The same thing was done on the pentagon and rectangular prism. This step was a finishing step to determine the formula from many sides, ribs and vertexes prism angle of pointn. This meant that SB could conclude what wasthe question about and also able to check it back. For this point, He / She got a score of 4. Based on this result, it could be said that SB was able to master the second indicator of mathematical reasoning by drawing the conclusion, compiling evidence, reasoning or evidencing some of good solutions from the questions.

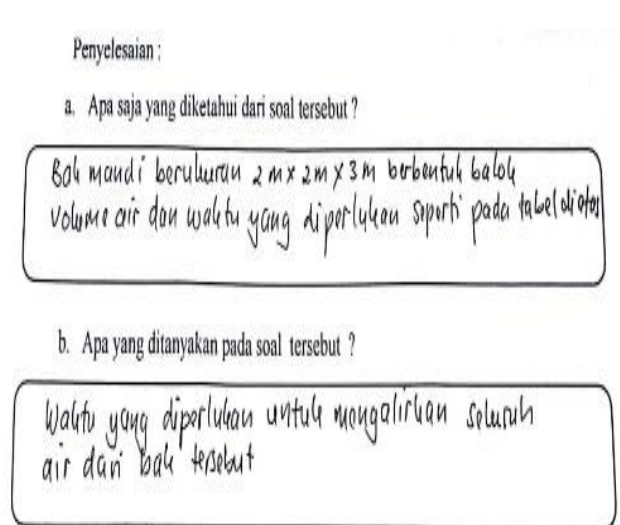

Figure 3. Students' answer in answering the Question of Indicator 3 c. Tuliskan javraban Anda

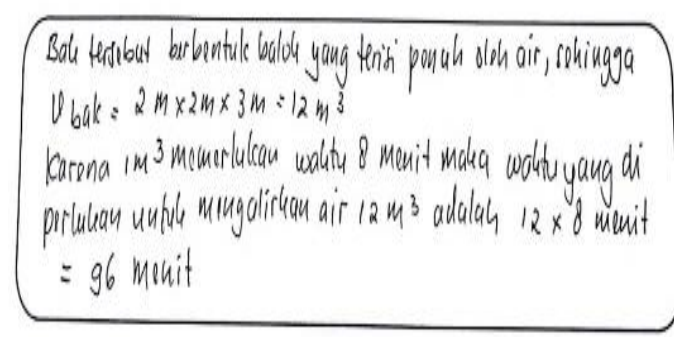
Anda d. Sectlum menuju ke pertanyaan selanjuthnya, cek kemblal jawaban

SB worked on Question 3 that asked about how much time that needed to drain the water into the tub until it would have filled. Some steps taken by SB to answer it were: 1) wrote down what was known about the exact form of a tub-shaped beams measuring of $2 \mathrm{~m} \times 2 \mathrm{~m} \times$ 
$3 \mathrm{~m}$ and filled up with the water. It meant SB understood the questions well. 2) wrote down what was being asked, which was: The time required to drain the entire water, it showed that SB did the initial planning as well. 3) answered correctly according to what was asked about, which was the time thatrequired 96 minutes with a volume of tub $12 \mathrm{~m}^{2}$. These results were obtainedfrom the observation of table. Based on the step (3) SB had shown steps to resolve as well as a step of checking back because SB could perform calculations and found the answers correctly about how much time taken for $1 \mathrm{~m}^{3}$ was 8 minutes. Hence, the time used to fill the bathtub was during 96 minutes. From the description above it could be concluded that the third indicator of mathematical reasoning was good such as drawing conclusions from statements, so SB got a score of 4 .

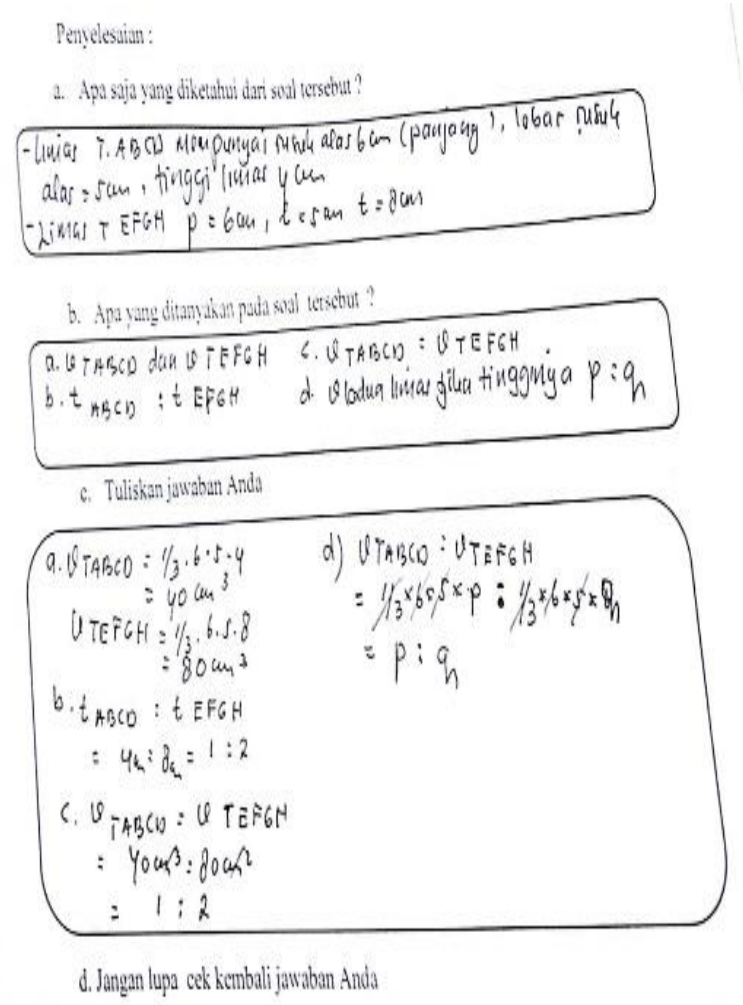

\section{Figure 4. Students' answer in answering the Question of Indicator 4}

SA did the question number 4 on volume of two pyramids that had a different height. Some steps that taken by SA were:1) wrote down what was He/ She known about the precise form of: (a) the length of ribs $=6 \mathrm{~cm}$, width ribs $=5 \mathrm{~cm}$, and height $=4 \mathrm{~cm}$ and (b) the length of ribs $=6 \mathrm{~cm}$, wide ribs $=5 \mathrm{~cm}$, and height $=6 \mathrm{~cm}$. It meant SA understood the questions very well. 2) wrote down what was being asked if the volume ratio of the pyramid and the volume of the high ratio were p: q, it meant SA performedthe beginning steps with understanding and proper planning. 3) answered correctly according to what was asked about, Volume of the pyramid T.ABCD $=40 \mathrm{~cm}^{2}$ with the formula $=\frac{1}{3} \mathrm{x}$ base area $\times$ height and volume of the pyramid T.EFGH $=80 \mathrm{~cm}^{2}$ with the same formula and the different height, and could determine the volume ratio T.ABCD pyramid and T.EFGH $=1: 2$. SA also able to find if the ratio of the height of the pyramid p: q, the volume of the pyramid was also in the ratio p: q. step 3 showed the steps to resolve Polya appropriately. The researcherdid re-checkingin the interview,then found that SA could explain how that answer came. Therefore SA received a score of 4 . It showed 
indicators 4 determined the pattern or nature of the symptoms of mathematical generalization in mathematical reasoning ability was achieved perfectly.

From the results of the work, it can be seen that subject SC had been able to fulfill the reasoning indicators. Therefore, it was needed for in-depth interview to the SC. Here were excerpts from the interview:

Researcher: Ok, now look at number 1 (Appendix 2)

SC : Read the question.

Researcher: Take a look back on your work, was it correct?

SC : (Taking into account the results of his work) $360 \mathrm{~cm}^{2}$ for its volume

Researcher: Ok, so for the first Question, was itclear?

SC : Yes Miss, it was clear.

Researcher: Now, see the second question (Appendix 2), was it correct?

SC : (Silence of the outcome of the work) I felt it was right, Miss.

Researcher: Please take a look one more time, was there something wrong?

SC: (Watching worksheet), sorry Miss, I less scrupulous.

Researcher: so how about the conclusion?

$S C$ : Its formula was number of vertices

Researcher: Notice the Question number 3 (Appendix 2). Was it clear?

SC: It was clear, Miss.

Researcher:Ok, then let's come to number 4, why the work was not resumed?

SC: I had forgotten how it worked, Miss.

Researcher: Now, please try to do it.

SC: Yes, Miss.

Researcher: Have you understood with the answer?

SC: Yes, Miss. I have Understood.

Researcher: Now about the formula of Prisma?

SC: (Silence) I do not know, Miss.

Researcher:According to your first steps, did you doitcorrectly?

Number 1

SC: Yes, Missbecause the formula was correct.

Researcher: Are you sure? Please try to examine it once again, take a look one by one from entering the length, width, height and he calculation. Was there anything wrong?

SC: (the subject paid attention to the answer sheet). Yes, Miss. The height should be $8 \mathrm{~cm}$ but I wrote $10 \mathrm{~cm}$. I wrote the wrong number.

Researcher: How could you write the wrong height?

$S C$ : Yes, I wrote it wrong. Then I did it incorrectly.

In the interview above, it showed that $\mathrm{SC}$ answer the question by using Polya stages. SC was very convinced by step process. SC mastered the concept of second question so the second indicator was fulfilled.The result of working sheet and the interview of question number 
2 were similar. The similarity was SC looked very confident and mastered the concepts of materials so that SC could draw exact conclusions.

Based on the result data analysis the students' mathematical reasoning ability of VIIIF grade of in State of Islamic Junior High School 1 Trenggalekcould be seen from the students' worksheets and interview. Students who have high mathematical reasoning abilities were the students who fulfilled almost all indicators of mathematical reasoning abilities, which were; (a) the ability to provide a conclusion, (b) the ability to predict the answers and solutions, (c) the ability to use patterns and relationships to analyze mathematical situations.

The following analysis were based on table 2 of students' math reasoning skills according to ability levels:Subjects with high mathematical reasoning abilities reach an average of around $74.22 \%$ of the observed subjects. For subjects with high ability reasoning ability categorized as having high mathematical reasoning ability.It could be shown by fulfilling three categorizations of indicators by ability to present a mathematical statement in writing, orally or drawing, tell the conclusions, preparethe evidence and givesome solutions.Subjects with mathematical reasoning abilities were averaged approximately $51.26 \%$ of the observed subjects. From the results of the students' work who have the ability to moderate, it could be seen that students were reaching the two of indicators measured, theywere; mathematical ability in writing, orally or drawing and drawing conclusions.Subjects with low mathematical reasoning capabilities reached about $44.44 \%$ of the observed subjects. From the results of students' work who had low capability, it could be seen that students were not able to fulfill the indicators of mathematical reasoning abilities that measured. They did not understand the given problem due to the lack of understanding about the concept.

This was in line with the statement mentioned by Linola, D., Marsitin, R., \& Wulandari, T (2017) and Mikrayanti (2016), state that mathematical reasoning abilities of learners in solving word problems was high. Learners with reasoning abilities as much as $4 \%$ lower categories, students with reasoning ability medium category by $32 \%$, and learners with high category reasoning abilities as much as $64 \%$ with the category of ;High, low and moderate.

\section{CONCLUSION}

The level of mathematical reasoning from 6 subjects of students from VIIIF grade of State of Islamic Junior High School 1 Trenggalek on the flat side Geometry subjectwas good with the average of $69.59 \%$. It fulfilled by three categories as follows: Students with high mathematical reasoningcould master the three indicators well. Students with moderate mathematical reasoningable to master the mathematical reasoning 2 indicator well. Subjects with low mathematical reasoning abilities could only master one indicator well and complete the question by using Polya step which were understanding the planning and completing well but only the fourth stage aboutrechecking was still lacking. It was proved from the test sheets and interviews conducted, that some of students could not explain their answers.

\section{REFERENCES}

Depdiknas. (2006) PERMENDIKNAS No. 22 Th. 2006 tentang Standar Isi untuk Satuan Pendidikan Dasar Dan Menengah. [Online] Tersedia: https://asefts63.files.wordpress.com/2011/01/permendiknas-no-22-tahun-2006standar-isi.pdf. Diakses dari laman web tanggal 10 Januari 2017

Iqbal. (2015) Kemampuan Penalaran Matematis Siswa Dalam Menemukan Rumus Barisan Aritmatika Berbantuan Alat Peraga Sederhana.USU CONFERENCE SYSTEMS, 
Linola D., Marsitin, R., \& Wulandari, T. (2017).Analisis Kemampuan Penalaran Matematis Peserta Didik dalam Menyelesaikan Soal Cerita di SMAN 6 Malang. Pi: Mathematics Education Journal, volume1 Nomor1 pp. 27-33

Mikrayanti.(2016) Meningkatkan Kemampuan Penalaran Matematis melalui Pembelajaran berbasis Masalah Suska Journal of Mathematics Education. Volume 02 Nomor 2 pp 97-102

Ministry of Singapore Education (2009) [ Online ] http://www.aps.sg/files/speeches/Speech-by Dr\%20Ng\%20Eng\%20Hen,\%2017\%20Sep\%202009.pdfdownload on 20 November 2017.

NCTM. (2000). Executive Summary Principles and Standards for School Mathematics. [Online]. Available on :https://asefts63.files.wordpress.com/2011/01/permendiknasno-22-tahun2006-standard-isi.pdf. Accessible from a web page dated January 10, 2017

Puspendik (Pusat Penilaian Pendidikan). (2012). Kemampuan Matematika Siswa SMP Indonesia Menurut Bechmark Internasional TIMSS 2011. Jakarta: Balitbang Kemendikbud.

Puspendik (Pusat Penilaian Pendidikan). (2016). Kemampuan Matematika Siswa SMP Indonesia Menurut Bechmark Internasional TIMSS 2015. Jakarta: Balitbang Kemendikbud.

Ruseffendi.(2006). Pengantar Kepada Membantu Guru Mengembangkan Kompetensinya dalam Pengajaran Matematika. Bandung: Tarsito

Shadiq, F. (2004).Penalaran, Pemecahan Masalah dan Komunikasi dalam Pembelajaran Matematika. Depdiknas Dirjen Dikdasmen PPPG Matematika, Yogyakarta.

Soedjadi.(2000). Kiat Pendidikan Matematika di Indonesia.Bandung: Dirjen Dikti Depdiknas.

Wahyudin.(2008). Pembelajaran \&Model-model pembelajaran:Pelengkap untuk meningkatkankompetensi pedagogis para guru dan calon guru profesional.Bandung: Mandiri.

Puspendik (Center for Educational Assessment). (2012). The Mathematics Ability of Junior High Schoolin Indonesia According to the International BechmarkTIMSS 2011. Jakarta: BalitbangKemendikbud.

Puspendik (Center for Educational Assessment). (2016). The Mathematics Ability of Junior High Schoolin Indonesia According to the International BechmarkTIMSS2015. According to the International Bechmark Jakarta BalitbangKemendikbud.

Ruseffendi. (2006). Introduction to Help Teachers for Developing Competence in Teaching Mathematics. Bandung: Tarsito

Sadiq, F. (2004). Reasoning, Problem Solving and Communication inlearning Mathematics, Education Ministry Director General Dikdasmen PPPGMathematics, Yogyakarta.

Soedjadi.(2000). Tips on Mathematics Education in Indonesia. Bandung: Directorate General of Higher Education.

Wahyudin,(2008). Education \& Learning Models: Complementary to improve the competencies of pedagogical teachers and professional prospective teachers.Bandung: Mandiri. 